74 巻 739 号 (2008-3)

\title{
ディスクブレーキの鳴きに及ぼすパッド面取りの影響*
}

\author{
大浦 靖 典*1, 栗田 裕*2, 松村 雄一*3
}

\section{Influence of Pad Chamfering on Disk Brake Squeal}

\author{
Yasunori OURA*4, Yutaka KURITA and Yuichi MATSUMURA \\ ${ }^{* 4}$ Department of Mechanical Systems Engineering, The University of Shiga Prefecture, \\ 2500 Hassaka-cho, Hikone-shi, Shiga, 522-8533 Japan
}

\begin{abstract}
This study presents experimental and analytical results about the influence of pad chamfering on squeal vibration in the disk-pad-caliper system, which is modeled after an actual disk brake. In the leading side of contact area, the disk and the $\mathrm{pad}^{-}$caliper vibrate with the same amplitude and the same phase at a point. We call this point "contact point". Chamfering of the pad on the leading edge decreases the sound pressure level of squeal and moves the contact point from the leading side to the center of the pad. On the other hand, chamfering of the pad on the trailing edge has no relation to the squeal vibration. To clarify the influence of chamfering on squeal, we analyzed the disk-padcaliper system as a surface contact analysis model, which combined the disk with pad-caliper by distributed springs.
\end{abstract}

Key Words: Self-Excited Vibration, Frictional Vibration, Modeling, Disk Brake, Squeal, Chamfering

\section{1. 緒言}

回転する円板に摩擦材を押し付けて制動するディ スクブレーキは，安定した効きを発揮するブレーキと して自動車や鉄道車両などに幅広く用いられている. 近年では, 高い摩擦係数や而摩耗性をもつブレーキパ ッドの開発によって, ディスクブレーキの小型軽量化 が進んでいる. その一方で, 制動時に発生するキーと いう甲高い鳴きが問題となっている. この鳴きに対す る簡単かつ有効な対策として, パッドの面取りがある. 末岡ら ${ }^{(1)}$ は, 浮動型ディスクブレーキの鳴き発生とパ ッド/ディスク間の接触位置関係に着目した実験を行 い，鳴きが適当なブレーキ力の大きさのときに発生す ること, インナ一側パッドのリーディング側をカット すると鳴きが発生しなくなることを見いだした. パッ ド支持剛性をリーディング側とトレーリング側で変え ることで鳴きを発生させ，パッドをカットすることに よる接触領域の変化で鳴きが収まることを示している. 中野ら ${ }^{(2)}$ は, 対向型のディスクブレーキで同様の結果を 示しているが，両者とも分布ばね定数は一様であると している. また, 鳴き発生の要因となる接触面圧の不 均一(3)に，面取りが与える影響も検討されていない.

著者らは, これまで, 摩擦接触部の剛性がもつ押付

\footnotetext{
* 原稿受付 2007 年 6 月 20 日.

*1 正員, 滋賀県立大学大学院工学研究科(乯522-8533 彦根市 八坂町 2500).

*2 正員, フェロー, 滋賀県立大学工学部.

*3 正員, 滋賀県立大学工学部[現：山梨大学].

E-mail : n21yooura@ usp.ac.jp
}

圧依存性と鳴きの関係を研究してきた. まず, 両端を 固定した板ばねの中央にパッドを取り付けることで, パッド支持岡性を対称にした鳴き試験機を作製し，鳴 きを発生させる実験を行った (4). その結果, ディスクに パッドを押し付ける圧力によって鳴きの音圧や周波数 が変化することが明らかになった．また，摩擦接触部 付近でディスクは並進運動, パッドは並進と回転の 2 自由度の運動をしていることが確認できた。

実験結果を基に，摩擦接触部を分布ばねで表した面 接触モデルを作成した ${ }^{(5)}$. 分布ばねの岡性を一様とする と鳴きは発生しないが，押付圧依存性をもたせるとデ イスクとパッドの振動が連成して系が不安定となり, 鳴きが発生した. また, 発生する鳴きの音圧や周波数 が異なる2種類のパッドの摩擦接触部の剛性を測定し, 剛性の大きさと押付圧依存性が異なることを示した(6).

本研究では，パッドの面取りによる摩擦接触部の剛 性分布の変化が鳴きに及ぼす影響を検討する.まず, 片側端面を面取りしたパッドを用いて鳴き実験を行う。 パッドを面取りする位置と量によって, 鳴きの発生す る押付圧の範讲や鳴き音圧, 摩擦接触部の振動がどの ように変化するかを測定する. 次に，面接触モデルを 用いて，パッドの面取りによる摩擦接触部の圧力や剛 性の分布の変化と鳴きの関係を考察する.

\section{2. 鳴き実験}

$2 \cdot 1$ 実験装置 実際のディスクブレーキの代わ りに構造が簡単な模擬的な装置を用いて，パッドの面 取りが鳴きに与える影響を調べた. ディスクの形状を 
図 1(a)に示す.ディスクを内周固定・外周自由の境界 条件を満たす鋼製の円板で模擬した. 外周部の厚さ $h$ は $6 \mathrm{~mm}$ である. パッド・キャリパの形状を図 1(b)に示 す. 自動車用パッドを $20 \mathrm{~mm} \times 20 \mathrm{~mm}$ に切り抜き, 長 さ $60 \mathrm{~mm}$, 幅 $20 \mathrm{~mm}$, 厚さ $t$ が $1 \mathrm{~mm}$ の鋼製の板ばね で支持した. パッドの面取りの位置と量が鳴きに与え る影響を調べるため, 片側端面を接触面に平行に $c[\mathrm{~mm}]$, 垂直方向に $0.5 \mathrm{~mm}$, 紙面垂直方向には $20 \mathrm{~mm}$ 全て切除した. パッドは 6 個用意し, 面取り量 $c$ は, 0 (面取りなし) $, 0.5,1.0,1.5,2.0,3.0 \mathrm{~mm}$ とした. パッドの取付け方向で，面取り位置を変更する. この ように面取り加工したパッドを一定速度 $40 \mathrm{rpm}$ で回転 するディスクに押し付け，摩擦接触部を連続スリップ 状態とし, 鳴きを発生させた. パッド中央を原点 0 と し, ディスクが回転してパッドに入る側をリーディン グ側 (一側), 出る側をトレーリング側 (十側) と呼ぶ.

$\mathbf{2} \cdot \mathbf{2}$ 鳴きの周波数と音圧レベルパッドの面 取りが鳴きの周波数と音圧に与える影響を，押付圧を 変えて調べた. まず，基準として，面取りしていない パッドを用いたときに発生した鳴きの周波数解析結果 を図 2 に示す. パッドをディスクに押し付ける荷重は $50 ， 100 ， 150 \mathrm{~N}$ とした. 図2より, どの押付荷重でも 鳴き周波数は $2032 \mathrm{~Hz}$ となることがわかる. $4 \mathrm{kHz}$ 付近 のピークは 2 倍高調波成分である. また, 押付荷重が 大きくなるほど，鳴き音圧レベルも大きくなる.

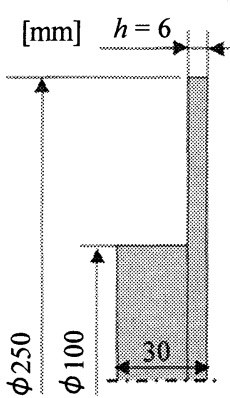

(a) Disk

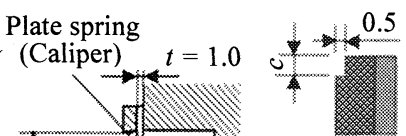

Leading side chamfering

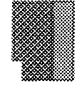

Trailing side chamfering (b) Pad-caliper

次に, パッドの面取りによる鳴き音圧レベルの変化 を調べた.このとき，発生した鳴きの周波数は，面取 りの位置と量によらず, 常に $2032 \mathrm{~Hz}$ となった. 図 3(a) に，パッドのリーディング側を面取りしたときの鳴き 音圧レベルの変化を示す. パッドにかける押付荷重は, $10 \mathrm{~N}$ から $150 \mathrm{~N}$ まで $10 \mathrm{~N}$ 刻みとした。図3の横軸は, 押付荷重を接触面積で割つた押付圧である. 試験機の 駆動音などが $35 \mathrm{dBA}$ 程度あるため, $40 \mathrm{dBA}$ 以上の音 圧をもつ音を鳴きと判別した，パッドの面取り量を大 きくすると，鳴きが発生し始める押付圧が高圧側に移 動することがわかる．また，押付荷重が 150 Nのとき の鳴き音圧レベルは，面取りしないときが約 $95 \mathrm{dBA}$, 面取り量が $1.0 \mathrm{~mm}$ のときは約 $80 \mathrm{dBA}$, 面取り量が $2.0 \mathrm{~mm}$ のときは約 $70 \mathrm{dBA}$ となる. 面取り量が $3.0 \mathrm{~mm}$ のときは，実験した押付圧の範囲では，鳴き自体が発 生しなかった. パッドのリーディング側を面取りする と，鳴きが発生しにくくなることがわかる．

図 3(b)に，パッドのトレーリング側を面取りしたと

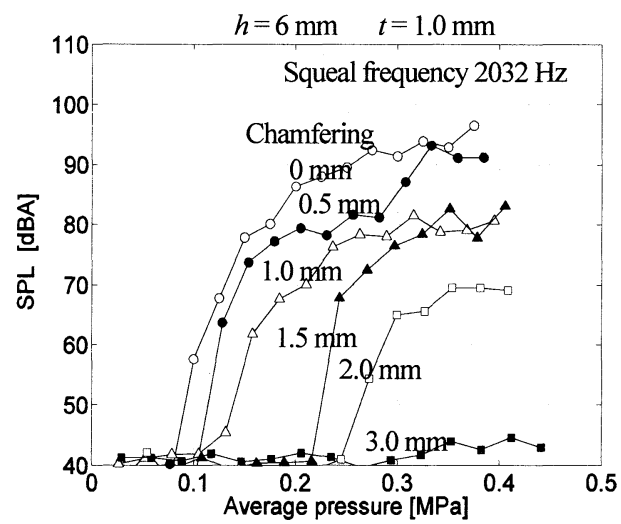

(a) Leading side chamfering

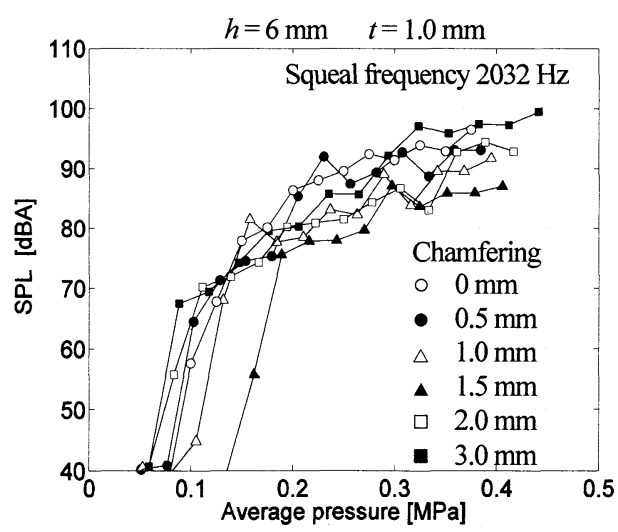

(b) Trailing side chamfering

Fig. 3 Influence of chamfering on sound pressure level

Fig. 2 Frequency analysis results of squeal noise

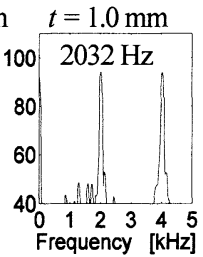

(c) $150 \mathrm{~N}$

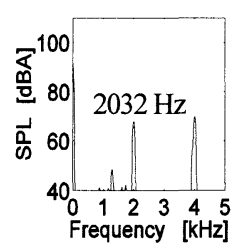

(a) $50 \mathrm{~N}$

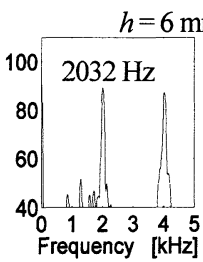

(b) $100 \mathrm{~N}$

Fig. 1 Shape of specimen 
きの鳴き音圧レベルの変化を示す，鳴きが発生し始め る押付圧は, どの面取り量においても $0.1 \mathrm{MPa}$ 付近と なった，また，面取り量によらず，鳴き音圧レベルの 最大值は $90 \mathrm{dBA}$ 以上となり, 面取りしていないときと 同等である. トレーリング側の面取りは，発生する鳴 きにほとんど影響がないことがわかる。
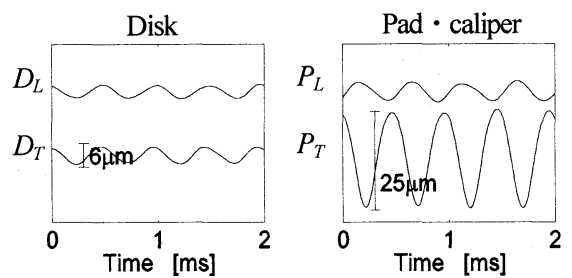

(a) Non chamfering $(c=0 \mathrm{~mm})$
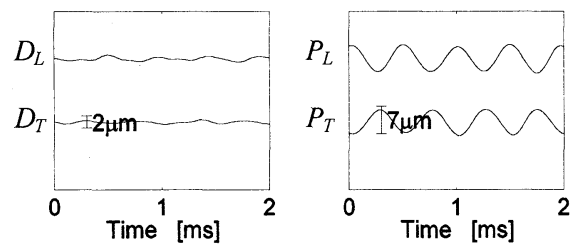

(b) Leading side chamfering $(c=2.0 \mathrm{~mm})$
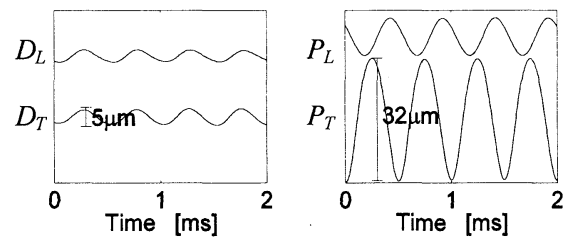

(c) Trailing side chamfering $(c=2.0 \mathrm{~mm})$

Fig. 4 Squeal vibration on contact area
$2 \cdot 3$ 摩擦接触部付近の振動 パッドの面取りに よる摩擦接触部付近の鳴き振動の変化を, 非接触変位 計で調べた. 変位計は, パッドの中央からリーディン グ側に $11 \mathrm{~mm}$ の位置とトレーリング側に $11 \mathrm{~mm}$ の位置 に，ディスク側とパッド・キャリパ側で対向するよう 設置した. 鳴き振動測定時の押付荷重は $100 \mathrm{~N}$ とした.

図 4(a)に，面取りしていないパッドを用いたときの 鳴き振動波形を示寸， $D_{L} ， D_{T}$ と $P_{L}, P_{T}$ は，それぞれ ディスクとパッド・キャリパのリーディング側 $(L)$, トレーリング側 $(T)$ の振動波形である. ディスクの 振動はリーディング側とトレーリング側で同位相・同 振幅となる. パッドの振動は, リーディング側とトレ 一リング側で逆位相となり，振幅はトレーリング側が 大きくなる，接触部では，ディスクとパッドの振動に 相対変位が生じていることがわかる.

図 4(b)に,リーディング側を $2.0 \mathrm{~mm}$ 面取りしたとき の鳴き振動波形を示す．面取りしていないときに比心゙ て, ディスクの振動もパッドのトレーリング側の振動 も振幅が小さくなることがわかる.

図4(c)に,トレーリング側を $2.0 \mathrm{~mm}$ 面取りしたときの 鳴き振動波形を示す．面取りしていないときに比べて, ディスクの振動はほとんど変化しないが, パッドの振 動の振幅がやや大きくなることがわかる。

パッドの面取りによる摩擦接触部付近の鳴き振動モ 一ドの変化を調べた．振動モードは，リーディング側 とトレーリング側の振動の測定值を直線で結ぶことで 表した. また，摩擦接触部において，ディスクとパッ ドの振動の振幅と位相が最も近くなる点（以下，接触

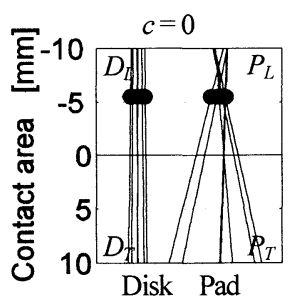

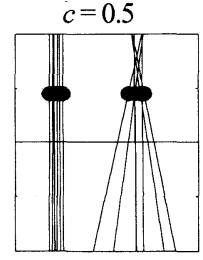

Disk Pad

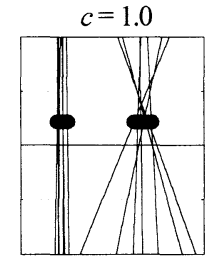

Disk Pad

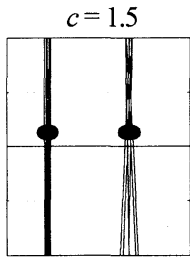

Disk Pad

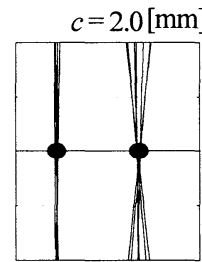

Disk Pad

(a) Leading side chamfering
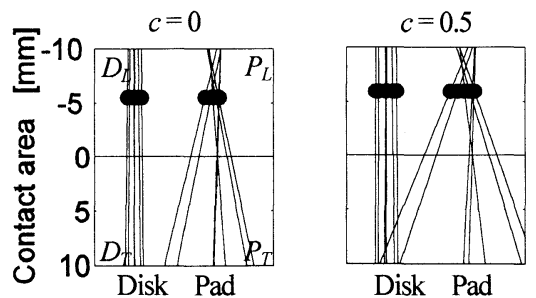

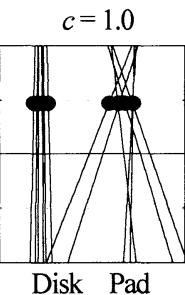

Disk Pad

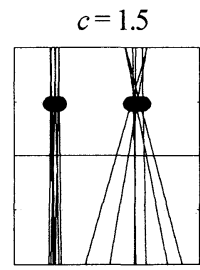

Disk $\mathrm{Pad}$

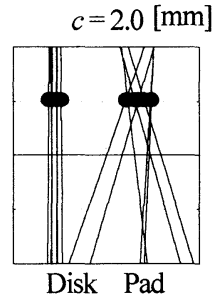

Disk Pad

(b) Trailing side chamfering

Fig. 5 Influence of chamfering on vibration mode in experiment 
点(4) と呼ぶ) の位置に面取りが与える影響を検討した. 前報 (5)の検討より，面取りが接触点の位置に与える影響 は, 接触部の岡性分布の重心の位置に与える影響と一 致すると考えられる.

図 5(a)に，パッドのリーディング側を面取りしたと きの摩擦接触部の振動モードの変化を示す. 面取り量 が大きくなるほど, ディスクの振動とパッドのトレー リング側の振動の振幅が小さくなることがわかる. 接 触点の位置（図中の・印）は，リーディング側 $5 \mathrm{~mm}$ 付 近からパッドの中央に移動する.

図 5(b)に, パッドのトレーリング側を面取りしたと きの摩擦接触部の振動モードを示す. 面取りによって, パッドの振動は振幅が全体的に少し大きくなるが，デ ィスクの振動は変化しない.このため, 振動モード自 体は，ほとんど変化しないことがわかる．上って，接 触点は常にリーディング側 $5 \mathrm{~mm}$ 付近に存在する.

接触点における振動を図6に示す.実線がディスク， 破線がパッドの振動である. 面取りしていないとき (図 6(a)）は, ディスクとパッドの振動が同位相・同振幅と なる. パッドのリーディング側を $2 \mathrm{~mm}$ 面取りしたと き(図 6(b)) は, ディスクの振動が小さくり, パッド もほとんど振動しない、トレーリング側を $2 \mathrm{~mm}$ 面取 りしたとき（図 6(c)）は, 全体的にパッドの振幅が大 きくなるので, ディスクとパッドの振動の振幅と位相 が最も近くなる点を接触点とした.

\section{3. 鳴き発生の理論}

3-1 面接触モデル 前報(5)の面接触モデルを用い て，パッドの面取りが鳴きに及ぼす影響を解析する.

図 7 に, ディスクを並進の 1 自由度, パッド・キャリ パを並進と回転の 2 自由度をもつ振動系で表した面接 触モデルを示す，パッド・キャリパの回転運動の中心 は，常にパッドを支持する板ばねの中央とした．ディ スクは，等価質量 $M$ と等価ばね定数 $K$ を用いて表す. パッド・キャリパの慣性モーメント $J$ は, 振動体全体 の質量 $m$ から算出した. 並進のばね定数 $k_{1}$ と回転のば ね定数 $k_{\varphi}$ は, 対応する振動モードの固有振動数から求

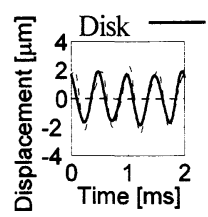

(a) None chamfering

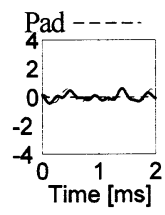

(b) Leading side $(c=2.0 \mathrm{~mm})$

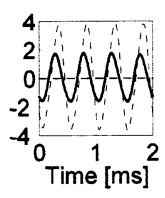

(c) Trailing side $(c=2.0 \mathrm{~mm})$
Fig. 6 Squeal vibration at contact position
めた. また, 接触面の摩擦係数 $\mu$ は実験より 0.3 である.

摩擦接触部は分布ばね $k$ を用いて表す。

面接触モデルの運動方程式を以下に示す. ディスク の並進方向の運動方程式は,

$$
M \ddot{x}_{d}=-K x_{d}-\int f d A
$$

パッド・キャリパの並進方向の運動方程式は,

$$
m \ddot{x}_{p}=-k_{t} x_{p}+\int f d A
$$

パッド・キャリパの回転方向の運動方程式は,

$$
J \ddot{\varphi}=-k_{\varphi} \varphi+\int \mu f l_{G} d A+\int f l d A
$$

接触部の各位置に生じる力を, 接触部の岡性 $k$ とディ スクとパッドの相詨変位 $x$ を用いて次式で表す. 接触 部の減衰は, 剛性に比べて非常に小さいため無視した( ${ }^{(9)}$.

$$
f(l)=k x=k\left(x_{d}-x_{p}-l \varphi\right)
$$

運動方程式をラプラス変換して行列式にまとめると,

$$
\begin{aligned}
& \left(\begin{array}{lll}
B_{11} & B_{12} & B_{13} \\
B_{21} & B_{22} & B_{23} \\
B_{31} & B_{32} & B_{33}
\end{array}\right)\left(\begin{array}{l}
X_{d} \\
X_{p} \\
\Phi
\end{array}\right)=0, \\
& B_{11}=M s^{2}+K+\int k d A, \quad B_{12}=B_{21}=-\int k d A, \\
& B_{13}=-B_{23}=-\int k l d A, \quad B_{22}=m s^{2}+k_{t}+\int k d A, \\
& B_{31}=-B_{32}=-\mu l_{G} \int k d A-\int k l d A, \\
& B_{33}=J s^{2}+\mu l_{G} \int k l d A+k_{\varphi}+\int k l^{2} d A
\end{aligned}
$$

式(5)の倸数行列の行列式 $=0$ が特性方程式であり, $s^{2}$ についての3 次式 (sについての6 次式) になる.この 特性方程式が共役複素根をもち, その実部が正となる ときに, 系は動的に不安定となり, 自励振動（鳴き） が発生する. 共役複素根の実部 $X$ の大きさは, 振動の 発散の速さを表すので，鳴きやすさと呼ぶ，鳴きやす さ $X$ の大きさ、鳴き音圧レベルの大きさに対応する.

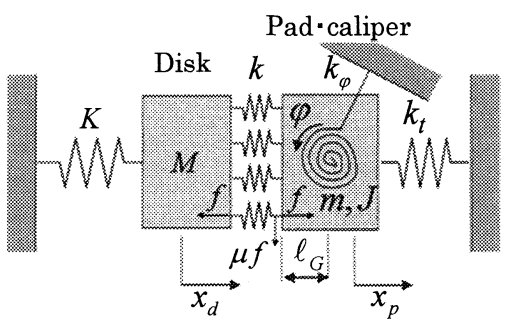

Fig. 7 Surface contact analysis model

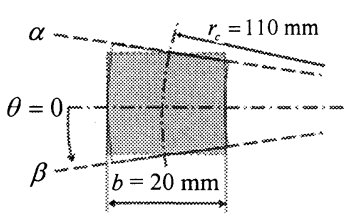

Fig. 8 Shape of contact area 
また，共役複素根の虚部は，鳴き周波数を表す.

面接触モデルにおける接触部の形状を図 8 に示す. 接触部のディスク半径方向の長さ $b$ は $20 \mathrm{~mm}$ とする. 円周方向の位置 $l$ は, ディスクの回転中心から接触面 中心までの距離 $r_{c}=110 \mathrm{~mm}$ とディスク回転中心から の角度 $\theta$ で表す．面取りしていないパッドでの接触部 の円周方向の長さ $20 \mathrm{~mm}$ は, リーディング側端までの 角度 $\alpha$ を- $0.09 \mathrm{rad}$, トレーリング側端までの角度 $\beta$ を $0.09 \mathrm{rad}$ として表す. 面接触モデルの運動方程式の積分 の範囲は $\alpha$ から $\beta$ までとなる．また，接触部の微小面 積は $d A=b r_{c} d \theta$ となる. パッドの面取りは, $\alpha$ や $\beta$ の 值を変えることで表す，ただし，パッド・キャリパの 質量 $m$ と慣性モーメント $J$, 面取りされる体積が微 小なため, 面取りしていないときと同じ値を用いた.

\section{$3 \cdot 2$ 摩擦接触部の剛性 面接触モデルで解析す} るために, 摩擦接触部の剛性の大きさと押付圧の関係 を式で表す必要がある. 接触部の剛性を求めるために, あらかじめ押付圧を加えたパッドをランダムノイズ加 振し, 接触部に生じる変位から加振力までの伝達関数 (動剛性)を測定した (6). 鳴きが発生する周波数域では, 動剛性に占める減衰の割合は, 剛性に比べて無視でき るほど小さい，そこで, 実験の鳴き周波数に近い $2 \mathrm{kHz}$ の動剛性の測定值を接触部の剛性とした.

図 9 に, パッドの接触部の剛性を，押付圧を変えて 測定した結果を示す，剛性の測定はパッドを面取りす る前に行った. 図中の凡例は測定後に行った面取り量 $c$ を表す. 接触部の剛性と押付圧の関係を次式で表す.

$$
k=K_{N} p^{N}
$$

押付圧が 0 のときの剛性は，十分に小さいと見なし 0 とした. 図 9 に式(6)による近似線を示す. 剛性の大き さを表す係数 $K_{N} を 6.98 \times 10^{8}$, 押付圧依存性を表す非線 形性指数 $N$ を 0.35 とした. これらの值を用いて，接 触部の剛性がもつ押付圧依存性を考慮した解析を行う。

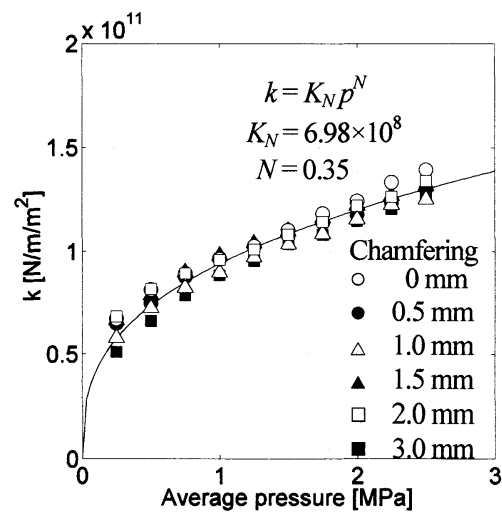

Fig. 9 Pressure versus stiffness in contact region
$3 \cdot 3$ 摩擦接触部の㓮性分布の重心 面接触モデ ルにおいて鳴きが発生する条件を考察する. 面接触モ デルの運動方程式である式(5)中の $B_{13}$ と $B_{23}$ は, ディス クとパッドの並進運動と, パッドの回転運動の連成項 の係数にあたる.もし, 係数 $B_{13}$ と $B_{23}$ が 0 であれば, 並進と回転の振動が連成せず, 系は不安定にならない. 連成項の大きさを接触部全体の剛性で割ると,

$$
l_{c}^{\prime}=\frac{\int k l d A}{\int k d A}
$$

式(7)は接触部の岡性分布の重心位置を表している. 実 験での接触点の位置 $l_{c}$ に対応する ${ }^{(5)}$. 剛性分布の重心位 置がパッドの中央となるとき，振動の連成項も 0 とな り鳴きは発生しない，岡性分布の重心位置で，鳴きが 発生する可能性を判断できる.

\section{4. 解析結果}

$4 \cdot 1$ 鳴きやすさと接触部の振動 面接触モデ ルを用いて, パッドの面取りが鳴きに与える影響を解 析した. 解析に用いる各係数は, 前報(5) と同じ值とした.

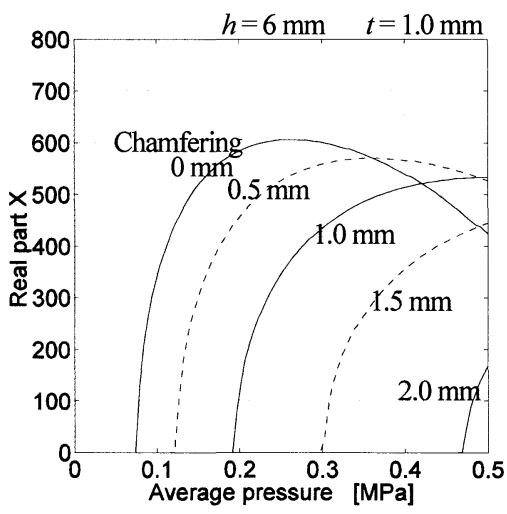

(a) Leading side chamfering

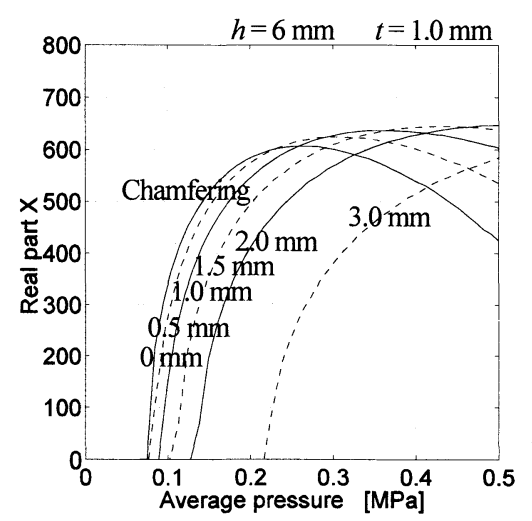

(b) Trailing side chamfering

Fig. 10 Influence of chamfering on real part X 
図10(a)に，パッドのリーディング側を面取りしたと きの押付圧と鳴きやすさの関係を示す．面取り量を大 きくすると，鳴きが発生し始める押付圧が高圧側に移 動し, 鳴きやすさの最大值が低下する.面取り量 $3.0 \mathrm{~mm}$ のときは, 押付圧に関係なく, 鳴き自体が発生しない. この解析結果は, パッドのリーディング側の面取りで 鳴きが低減することを示しており, 実駼結果と傾向が 一致する．ただし，解析結果の方が，面取りの効果が 大きく現れている.

図 10(b)に, パッドのトレーリング側を面取りしたと きの解析結果を示す．面取り量を大きくしても，鳴き が発生し始める押付圧や鳴きやすさの最大值はあまり 変化しない，この解析結果は，トレーリング側を面取 りしても鳴きへの影響が小さいことを示しており，実 験結果と一致する.

次に，パッドの面取りによって，摩擦接触部の鳴き 振動がどのように変化するのかを解析した. 解析での 押付荷重は実験と同じ $100 \mathrm{~N}$ とした. 図11(a)に，パッ ドのリーディング側を面取りしたときの鳴き振動モー ドの変化を示す. 図中の・印は, 接触部の岡性分布の重 心位置である.この位置は, 前報(5)での検討より, 接触 点位置に対応すると考えられる. パッドの面取り量を 大きくすると,・印は接触部のリーディング側から中央 に向けて移動することがわかる. 面取り量が $1.5 \mathrm{~mm}$ 以 上のときは, 解析では鳴きが発生しなくなる.

図 11(b)に，パッドのトレーリング側を面取りしたと きの振動モードを示す，面取り量を大きくすると，

・印が接触部のリーディング側に移動するが, 移動量は
リーディング側を面取りしたときに比べて小さい，実 験と解析より，リーディング側の面取りは，トレーリ ング側の面取りに比べて，剛性分布の重心（接触点） の位置と鳴きに与える影響が大きいことがわかる。

図 12 に, 摩擦接触部の剛性分布の重心位置でのディ スクとパッドの振動を示す.ディスクの振動を基準 (振 幅 1)として,パッドの振動の振幅比と位相差を求めた. 実線がディスク，破線がパッドの振動である，パッド を面取りしていないとき（図12(a)）は，ディスクとパ ッドがほぼ同位相となり, 振動の振幅も接触部の他の 位置より近い值となる.リーディング側を $2 \mathrm{~mm}$ 面取 りしたとき（図 12(b)）は，鳴き振動が発生しない。卜 レーリング側を $2 \mathrm{~mm}$ 面取りしたとき（図 12(c)）は, 振動の位相はほぼ一致し，パッドの振幅が少し大きく なる. 剛性分布の重心位置での振動は, 図6で示した, 接触点の位置での振動に近いことがわかる.

4.2 接触部の圧力と剛性の分布 パッドの面取 りによって，接触部の圧力と剛性の分布がどのように 変化するかを解析した. 図13(a)に, パッドを面取りし

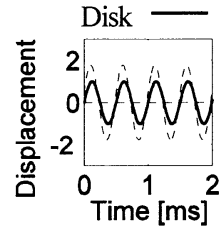

(a) None chamfering

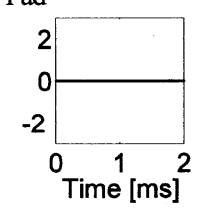

(b) Leading side $(c=2.0 \mathrm{~mm})$

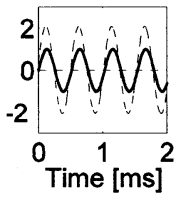

(c) Trailing side $(c=2.0 \mathrm{~mm})$
Fig. 12 Squeal vibration at $l_{c}^{\prime}$
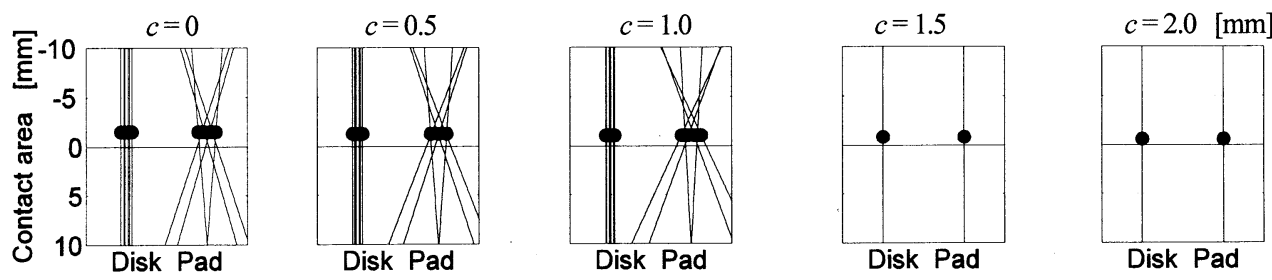

(a) Leading side chamfering
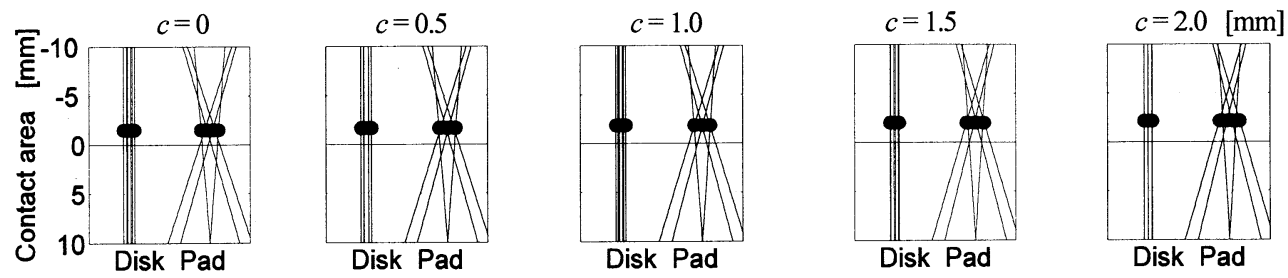

(b) Trailing side chamfering

Fig. 11 Influence of chamfering on vibration mode in analysis 

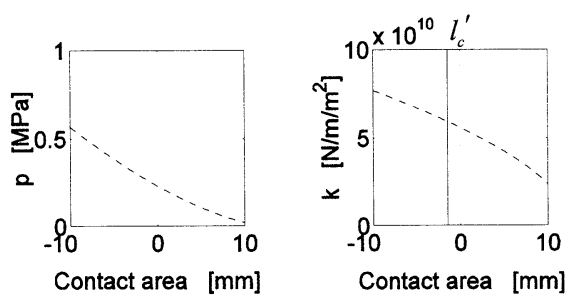

(a) Non chamfering $(c=0 \mathrm{~mm})$
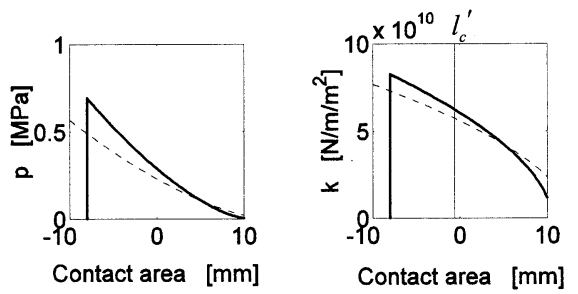

(b) Leading side chamfering $(c=2.0 \mathrm{~mm})$
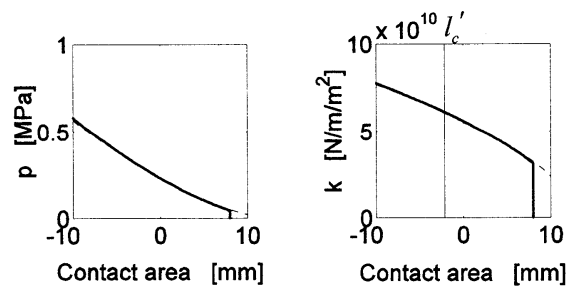

(c) Trailing side chamfering $(c=2.0 \mathrm{~mm})$

Fig. 13 Chamfer influence on stiffness distribution

ていないときの接触部の圧力 $p$ と剛性 $k$ の分布を解析 した結果を破線で示す. また, 接触部の剛性分布の重 心位置(リーディング側 $1.5 \mathrm{~mm}$ )を縦の実線で示す. 押 付圧の分布はほぼ三角形となり, リーディング側端で 最大值となる. このとき, 接触部の剛性も, 押付圧依 存性によって, リーディング側端で最大值, トレーリ ング側端で最小值をもつ.

図 13(b)に，パッドのリーディング側を $2.0 \mathrm{~mm}$ 面取 りしたときの接触部の圧力と岡性の分布を実線で示す. また, 面取りしていないときの分布を破線で示す. 最 も剛性が大きくなるリーディング側端が面取りされる ため, 剛性分布の重心位置はパッドの中央側に移動し, リーディング側 $0.6 \mathrm{~mm}$ となる. このとき, ディスクと パッドの振動の連成項の係数 $B_{13}$ と $B_{23}$ も小さくなり, 鳴きが発生しなくなる.

図 13(c)に，パッドのトレーリング側を $2.0 \mathrm{~mm}$ 面取 りしたときの接触部の圧力と剛性の分布を示す. トレ 一リング側の面取りによって, 剛性分布の重心位置が リーディング側 $2.1 \mathrm{~mm}$ に移動する. ただし, トレーリ ング端は接触面内で最も圧力が小さいため, 圧力（剛 性）の分布の形状はほとんど变化しない.

\section{5. 結}

構造の簡単な鳴き試験機と面接触モデルを用いて, パッドの面取りによる摩擦接触部の圧力と剛性の分布 の変化が鳴きに与える影響を検討した.

（1）パッドのリーディング側を面取りすると，鳴き が発生する押付圧の範囲が狭くなり，鳴き音圧の最大 值が低下する．これに対して，トレーリング側を面取 りしても発生する鳴きはほとんど変わらない.

（2）パッドのリーディング側を面取りしたときは, 接触点の位置がパッドの中央側に移動する.これに対 して，トレーリング側を面取りしたときは，接触点の 位置はほとんど変化しない，

（3）面接触モデルの解析より, パッドの面取りによ って, 接触部の岡性分布の重心位置がパッドの中央に 移動すると鳴きが発生しないことが明らかとなった。

\section{謝辞}

本研究では, 西澤幸男氏をはじめとする株式会社ア ドヴィックスの方々に多大な御支援を頂いた。 また, 滋賀県立大学工学部の中川平三郎教授にはパッドの加 工を御指導頂いた。 ここに記して謝意を表す。

\section{文献}

(1) Sueoka , A. , Ryu , T., Shirozu , K., and Ichiba ,Y., Squeal of Disk Brake of Floating Type for Cars (Ist Report, Relationship between Occurrence of Squeal and Contact Region between Rotor and Pads in Experiment), Transactions of the Japan Society of Mechanical Engineers, Series C, Vol.67, No.658 (2001), pp.1719-1726.

(2) Nakano, Y., Ryu, T., and Sueoka, A. , Squeal of Rigid Type Disk Brake for Car , Transactions of the Japan Society of Mechanical Engineers, Series C, Vol.70, No.700 (2004), pp.3398-3405.

(3) Maekawa, M., Matsuda, T., Sato, M., and Sinbori, M., Researches on Brake Noise in Disc-Brake System for Automobiles (Generating Mechanism of Uneven Wear on Friction Surface of Pad), Journal of Japan Society for Design Engineering, Vol.39, No.4 (2004), pp.189-194.

(4) Kurita, Y., Matsumura, Y., Ito ,A. ,Tamura ,T. and Oura, Y., Squeal Vibration in Disk Brake, Transactions of the Japan Society of Mechanical Engineers, Series C, Vol.70, No.694 (2004), pp.1609-1615.

(5) Oura, Y., Kurita, Y., Matsumura, Y. and ,Tamura, T., Surface Contact Analysis Model for Squeal on Disk Brake, Transactions of the Japan Society of Mechanical Engineers, Series C, Vol.73, No.731 (2007), pp.1977-1984.

(6) Oura, Y., Kurita, Y. and Matsumura, Y., Influence of Dynamic Stiffness in Contact Region on Disk Brake Squeal, Transactions of the Japan Society of Mechanical Engineers, Series C, Vol.73, No.731 (2007), pp.1985-1991. 